\title{
Difference between Supervision on Approvals of Parliament and Executive Branch in Islamic Republic of Iran
}

\author{
Mohammad Hassan Habibi ${ }^{1}$, Mansour Naroui ${ }^{2}$ \\ ${ }^{1}$ Department of Law, International Unit of Qeshm, Islamic Azad University, Qeshm, Iran \\ ${ }^{2}$ Master student, Department of Law, International Unit of Qeshm, Islamic Azad University, Qeshm, Iran
}

\begin{abstract}
The law is not defined in the Constitution of Iran. To distinguish between the rights and any other government systems, some legal writers have said that that part of the government which is permanent and general is called law. The research method is descriptive and analytical. In this study, documentary and desk studies are used to gather information by referring to related books, articles and websites. In fact, each reference is referred in order of chapters and topics, and first note-taking is done from all references for the issues related to the first chapter and after the end of this chapter, the next chapters are addressed similarly. Regulatory position in the executive branch: After the Supreme Leader, the President is the highest official of the country and assumes responsibility for the enforcement of the Constitution and heads the executive branch except in issues directly related to the Leader.
\end{abstract}

Keywords: Supervision, Parliament, Executive Branch, Iran

\section{Introduction}

The law is not defined in the Constitution of Iran. To distinguish between the rights and any other government systems, some legal writers have said that that part of the government which is permanent and general is called law. But, in terms of form, the advantage of law over other legal rules is in the legislation process. Any regulation approved by the Parliament based on the terms of the Constitution is a law, but its establishment and enforcement depends on the approval of the Guardian Council for non-compliance with the Constitution and Sharia, as well as the presidential signature is needed (articles 58, 94 and 132 of the Constitution). It follows from the foregoing that the law is very different from administrative rules in terms of validity and issuance process. The major differences can be summarized as follows:

1) In terms of legislation process: The law is resulted from the legislative branch and its legislature conditions are determined by the Constitution but administrative regulations and ratifications are set by the executive branch without the need for special processes.

2) The law governs all people and government agencies and if it is approved and signed in accordance with the Constitution, no authority can repeal it. Only the legislature branch can repeal it, explicitly or implicitly, by approving another law. But the validity of the executive branch approvals is limited to the provisions of laws, and they are valid if they are not against the Parliament approvals. In this case, not only the courts should refrain from applying such approvals (Article 170 of the Constitution), but also each beneficiary is entitled to ask the Administrative Justice Court to invalidate them.

In addition, administrative regulations and ratifications do require the executive branch because the approval authority or a higher authority can abrogate it with a new approval (Katozian, 2014).
Accordingly, the aim of this thesis is to explore the difference between supervision of the approvals of the executive branch and the legislature branch and introduce supervision institutions in both branches.

Mr. Vijeh (2014), in an article entitled "Evaluation of supervisory jurisdiction of the Parliament Speaker over the government approvals, says that: "Supervision" is a public's right keyword and a prerequisite for the realization of all other principles of basic rights, such as the separation of powers, protection of the Constitution and rule of the law. Analysis of the supervisory jurisdiction in the legal system of the Islamic Republic of Iran is predicted for the Parliament Speaker in articles 85 and 138 of the Constitution. The application mechanism of this jurisdiction supplements the supervision of the Administrative Justice Court and the GIO. However, with subsequent extensions to the law, the legislator gradually transformed it. The main objective of this study is to answer this question: "Does the legislation supervision practice by Parliament differ from supervision of legislation by the executive branch?" This applied study can be used by academics, lawyers, judges, the judiciary in the Administrative Justice Court and the Supreme Court in order to inform students and apprentices of regulatory agencies of the legislature and executive branches and their work procedures, the limits of their jurisdiction, supervision process and types of supervision procedures including legal and judicial.

\section{Research Method}

The research method is descriptive and analytical. In this study, documentary and desk studies are used to gather information by referring to related books, articles and websites. In fact, each reference is referred in order of chapters and topics, and first note-taking is done from all references for the issues related to the first chapter and after the end of this chapter, the next chapters are addressed similarly. Moreover, the jurisdiction limits of regulatory bodies of the legislature and executive branches and their 


\section{International Journal of Science and Research (IJSR) \\ ISSN (Online): 2319-7064}

Index Copernicus Value (2013): 6.14 | Impact Factor (2014): 5.611

work procedures, supervision process and types of supervision procedures including legal and judicial are discussed.

\section{Theoretical Framework}

Direct supervision of the President: Supervision on the enforcement of the Constitution: According to Article 113 of the Constitution, the President heads the executive branch, is the highest authority in the country after the leader and is responsible for implementing the Constitution. Naturally, the proper enforcement of the Constitution can be guaranteed only through regular, accurate and consistent supervision. In Article 113 of the Constitution on "Law to determine the powers and responsibilities of the President of the Islamic Republic of Iran," regulations are as follows:

1) In order to safeguard the Constitution of Islamic Republic of Iran and for the enforcement of Article 113 of the Constitution, the President is responsible for enforcement of the Constitution through supervision, getting information, audit, track, review and necessary actions.

2) In case of violation or non-enforcement of the Constitution, the President may act, at his discretion, through warnings, prosecution and referring violators to courts.

\section{The Role of Supervision}

The rule of the law in the Constitution of Iran is as follows, according to Article 56 of the Constitution: "Absolute sovereignty over the world and man belongs to God and he has made man the ruler of his social destiny. No one can deny this divine right or use it for the interests of a particular individual or group, and the nation applies this divine right through the following principles."

There are two types of legislation in the Constitution based on the sovereignty of the people: 1 . direct legislation by the people, and 2. legislation by the Parliament. Direct legislation is predicted in Article 59 of the Constitution through referendum. According to Article 59 of the Constitution, "In very important economic, political, social and cultural issues, legislative acts may be taken by a referendum and direct reference to the popular vote. The demand of public opinion must be approved by the twothirds of MPs." Supervision in the Constitution: All civil, criminal, financial, economic, administrative, cultural, military, political rules and regulations must be based on Islamic criteria. This principle governs all principles of the Constitution and other rules and regulations, and its recognition rests with the Guardian Council jurists. After the elections, meetings of Parliament are recognized with the presence of the two thirds of MPs and the plans and bills are adopted in accordance with the internal regulation unless a specific quorum is set by the Constitution. To approve the internal regulation, the confirmation of the two-thirds of those present in the Parliament is required. Supervision on the Constitution: The Leader's supervision on the Constitution is expected in two ways: 1. Compliance of approvals with the Constitution: From the perspective of the Constitution, the Parliament cannot make laws incompatible with the Constitution. The Leader's supervision in this field is made through the Guardian
Council. Identification of non-compliance of the Parliament approvals with the Constitution rests with a majority of the Guardian Council members. Supervision on approvals and regulations for non-compliance with the principles of the Constitution is in fact a guarantee of the enforcement of the Constitution. 2. Enforcement of unused articles of the Constitution: Three decades of the enforcement of the Constitution shows that the presidents of Iran have been always faced with challenges in enforcement of Article 113 and have not managed to provide solutions for the enforcement of unused principles of the Constitution, even the formation of the Supervision Board of the Enforcement of the Constitution in the $8^{\text {th }}$ government was a failure (proceedings of the Expediency Council, 1991).

Sanction of the Parliament Speaker's supervision: In Article 126 of the Constitution prior to the revision in which the president was responsible for supervision of the government approvals, the government approvals were invalid before the announcement of the President (Proceedings of the Guardian Council, 2002: 142). Although in the revision 1989 with the aim of non-interference in national executive affairs, it was decided that the government approvals, in addition to notification for enforcement, must be sent to the Parliament Speaker for ensuring compliance with laws (Proceedings for the Review Council of the Constitution of Islamic Republic of Iran, 1985, vol. 2: 997-994), the nature of the action did not change. Thus, given that Article 138 of the Constitution considers the Parliament Speaker as the supervision authority for the approvals of the executive branch and according to the context of Article 138 of the Constitution (which is similar to Article 126 of the Constitution approved 1980) and the proceedings of the Parliament for final evaluation of the Constitution (proceedings of the Parliament for final evaluation of the Constitution of Islamic Republic of Iran, 1988, Vol. 2: 1272-1277) and the Constitution Council Review (proceedings for the Review Council of the Constitution of Islamic Republic of Iran, 1988, vol. 2: 9901013) with opinion of the Parliament Speaker, the Parliament law in relation to the non-compliance of government approvals with the law, the government is obliged to follow the Parliament Speaker's opinion. If the government insists on its approval, the approval is invalid due to the conflict with the law.

Regulatory position in the executive branch: After the Supreme Leader, the President is the highest official of the country and assumes responsibility for the enforcement of the Constitution and heads the executive branch except in issues directly related to the Leader. The old article: After the Supreme Leader, the President is the highest official of the country and assumes responsibility for the enforcement of the Constitution and regulates the relations of the three powers, and heads the executive branch except in issues directly related to the Leader. According to Article 122, the President within his powers and duties, according to the Constitution or normal laws, is responsible for the people, the Leader and the Islamic Consultative Assembly (according to the Islamic Republic of Iran Constitution, with reforms of 1989).

\section{References}

[1] Akhoondzadeh, M. F., Writings of Kamal al-Doleh and Jalal al-Doleh, Manuscript No. 1123/F, National Library 


\section{International Journal of Science and Research (IJSR) \\ ISSN (Online): 2319-7064}

Index Copernicus Value (2013): 6.14 | Impact Factor (2014): 5.611

[2] Aghaee and Ali Babaee, Culture of Political Science, Vol. 1, p. 4.

[3] Altman, A., What is the rule of law? Translated by Said Pezeshk Marandi

[4] Ibn Tora, M., 2006, Principle of justice in Islamic legislation system, Journal of Jurisprudence and Family Law, No. 44

[5] Badamchi, H., 2003, Begining of legislation. History of law in ancient Mesopotamia, Tehran, Tarhe No, p. 15

[6] Bagherzadeh, A., 2006, Jurisprudence and legislation, Journal of Religion and Spirituality, No. 11

[7] Bagheri Urumi, A., 2008, Religious community and religious concepts, First Edition, p. 141

[8] Bellamy, R., 2005, Political shape of the Constitution, separation of powers, individual rights and representative democracy, translated by $\mathrm{M}$. Hasanvand, p. 88

[9] Pasha Saleh, A., 2004, History of law, vol. 2, p. 414

[10] Pirnia (Moshir al-Doleh), H. and Iqbal Ashtiani, A., 1967, The course of Iranian history, vol. 4, p. 31

[11] Turkoman, M., 1984, Epistles, writings and notices of Sheikh Fazlullah Nuri, First Edition, p. 194

[12] Jafari Langroodi, M.J., 1997, Legal terminology

[13] Jones, W.T, 1997, Lords of political thought, Translated by Ali Ramin, Vol. 2, Tehran, Scientific and Cultural Press, First Edition, p. 850

[14] Haeri, K., 1999, The basics of government in Islam, Tehran, Congereh Press, Vol. 2, p. 197

[15] Hosseinali Zadeh, A., Administrative councils, Master thesis of public law, Shahid Beheshti University, School of Law, 1999, pp. 1-2. 